\title{
Corynebacterium marinum sp. nov. isolated from coastal sediment
}

\author{
Zong-Jun Du, ${ }^{1}$ Elizabeth M. Jordan, ${ }^{2}$ Alejandro P. Rooney, ${ }^{3}$ \\ Guan-Jun Chen ${ }^{1}$ and Brian Austin ${ }^{2,4}$ \\ ${ }^{1}$ College of Marine Science, Shandong University at Weihai, Weihai 264209, PR China \\ ${ }^{2}$ School of Life Sciences, Heriot-Watt University, Riccarton, Edinburgh EH14 4AS, UK \\ ${ }^{3}$ National Center for Agricultural Utilization Research, Agricultural Research Service, \\ US Department of Agriculture, 1815 North University Street, Peoria, IL 61604, USA \\ ${ }^{4}$ Institute of Aquaculture, University of Stirling, Stirling FK9 4LA, Scotland, UK
}

Correspondence

Brian Austin

brian.austin@stir.ac.uk

\begin{abstract}
A taxonomic study was performed on strain $\mathrm{D} 7015^{\top}$, which was isolated from coastal sediment close to a coal-fired power station in Qingdao, China. Cells of strain D7015 ${ }^{\top}$ were Gram-positive, non-motile, diphtheroid rods that grew in the presence of $0-8 \%(\mathrm{w} / \mathrm{v}) \mathrm{NaCl}$ and at $4-37^{\circ} \mathrm{C}$, with optimum growth at $1 \%(\mathrm{w} / \mathrm{v}) \mathrm{NaCl}$ and $30-32{ }^{\circ} \mathrm{C}$. The DNA G $+\mathrm{C}$ content was $65.0 \mathrm{~mol} \%$. The major fatty acids were $\mathrm{C}_{18: 1} \omega 9 \mathrm{c}(56.18 \%), \mathrm{C}_{16: 0}(38.02 \%), \mathrm{C}_{16: 1} \omega 7 \mathrm{c}(4.45 \%), \mathrm{C}_{18: 0}(1.0 \%)$ and $\mathrm{C}_{14: 0}(0.35 \%)$. On the basis of morphological, physiological and phylogenetic characteristics, strain D $7015^{\top}$ was classified in the genus Corynebacterium. It exhibited a $16 \mathrm{~S}$ rRNA gene sequence similarity of $95.9 \%$ and a DNA-DNA relatedness value of $20.4 \%$ with Corynebacterium halotolerans DSM $44683^{\top}$. Strain $\mathrm{D} 7015^{\top}$ was sufficiently different from recognized species of the genus Corynebacterium to be considered to represent a novel species. The name Corynebacterium marinum sp. nov. is proposed, with strain D7015 ${ }^{\top}$ (=CGMCC $1.6998^{\top}=\mathrm{NRRL} B-24779^{\top}$ ) as the type strain.
\end{abstract}

The genus Corynebacterium was proposed by Lehmann \& Neumann (1896) and represents a large group of Grampositive, asporogenous, rod-shaped bacteria with high DNA $\mathrm{G}+\mathrm{C}$ contents. Corynebacteria have been isolated from a wide range of environments, namely dairy products, soil, sewage, sediments, plant materials and aquatic sources, but the majority of novel species described in recent years have originated from human or animal clinical samples (e.g. Renaud et al., 2007; Yassin \& Siering, 2008; Yassin, 2009; Funke et al., 2009). However, some corynebacterial species have been isolated from the marine environment and they may occur as part of the indigenous flora of marine animals. For example, Corynebacterium phocae and Corynebacterium caspium were isolated from seals (Pascual et al., 1998; Collins et al., 2004), Corynebacterium spheniscorum and Corynebacterium sphenisci were recovered from wild penguins (Goyache et al., 2003a, 2003b), and Corynebacterium maris Coryn- $1^{\mathrm{T}}$ was found in the mucus of the coral Fungia granulosa (Ben-Dov et al., 2009). Here, the taxonomic characteristics of a novel Corynebacterium isolate that

The GenBank/EMBL/DDBJ accession number for the $16 \mathrm{~S}$ rRNA gene sequence of Corynebacterium marinum $\mathrm{D} 7015^{\top}$ is DQ2 19354 .

A representative phase-contrast micrograph of cells of strain $D 7015^{\top}$ (Fig. S1) and cellular fatty acid profiles of strain D7015 ${ }^{\top}$ and related species (Table S1) are available with the online version of this paper. originated from coastal sediment close to a coal-fired power station in Qingdao, China, are reported.

Strain $\mathrm{D} 7015^{\mathrm{T}}$ was isolated from coastal sediment in 2000 (Du et al., 2002). The isolate was grown aerobically at $28{ }^{\circ} \mathrm{C}$ on marine agar 2216E (MA; Difco) for $48 \mathrm{~h}$. Cultures were maintained on MA slants at room temperature and stock cultures were kept in tryptone soya broth (Oxoid) supplemented with $1 \%(\mathrm{w} / \mathrm{v}) \mathrm{NaCl}$ and $20 \%(\mathrm{v} / \mathrm{v})$ glycerol at $-70{ }^{\circ} \mathrm{C}$. Identification of strain $\mathrm{D} 7015^{\mathrm{T}}$ was performed as described by Jordan et al. (2007). For phenotypic tests, the strain was grown on MA for $48 \mathrm{~h}$ at $28{ }^{\circ} \mathrm{C}$ and cells were resuspended in saline for use as an inoculum. Tolerance to $1,3,5,7,8$ and $10 \%(\mathrm{w} / \mathrm{v}) \mathrm{NaCl}$ was assessed on appropriately modified tryptone soya agar (TSA; Oxoid). Growth in the absence of $\mathrm{NaCl}$ was assessed on plate count agar (Oxoid). Inoculated plates were incubated at $28{ }^{\circ} \mathrm{C}$ for up to 5 days. The effects of different temperatures on growth were assessed on TSA plates supplemented with $1 \%(\mathrm{w} / \mathrm{v}) \mathrm{NaCl}$ incubated at 4, 10, 15, $28,30,32,37,42$ and $45{ }^{\circ} \mathrm{C}$. Nitrate reduction was assessed in nitrate broth, prepared according to the method of Cowan \& Steel (1974), incubated at room temperature for 10 days. Oxidase and catalase activities were determined by using standard methods. The culture was characterized biochemically using the API Coryne, API $50 \mathrm{CH}$ and API 
ZYM systems according to the manufacturer's instructions (bioMérieux). Turbidity measurements were used to evaluate growth of strain $\mathrm{D} 7015^{\mathrm{T}}$ in the API $50 \mathrm{CH}$ and the API 20NE systems. API 50CH strips were read after 7 days incubation at $28{ }^{\circ} \mathrm{C}$.

The almost-complete 16S rRNA gene sequence (1444 nt) of strain $\mathrm{D} 7015^{\mathrm{T}}$ was obtained using the universal primers 27f and 1492r (MWG Biotech; Lane, 1991). The 16S rRNA gene sequence of strain $\mathrm{D} 7015^{\mathrm{T}}$ was submitted to GenBank and EMBL to search for similar sequences using the BLAST algorithm. A phylogenetic dendrogram of strain D7015 and some closely related members of the genus Corynebacterium based on 16S rRNA gene similarities was constructed using the neighbour-joining method of the MEGA software version 4.1 (Tamura et al., 2007). The resultant tree topologies were evaluated by bootstrap analysis based on 1000 replicates.

Cellular fatty acids were determined on a 3-day-old culture grown on MA plates after incubation at $28{ }^{\circ} \mathrm{C}$. Fatty acids were extracted, methylated and analysed using the standard MIDI (Microbial Identification) system (Sasser, 1990). The DNA G $+\mathrm{C}$ content was determined directly by HPLC as described previously (Tamaoka \& Komagata, 1984; Mesbah et al., 1989). DNA-DNA hybridization between strain $\mathrm{D}^{2} 715^{\mathrm{T}}$ and Corynebacterium halotolerans DSM $44683^{\mathrm{T}}$ was performed by applying the optical renaturation method (De Ley et al., 1970; Huß et al., 1983; Jahnke, 1992) under optimal hybridization conditions.

Microscopic examination of strain $\mathrm{D} 7015^{\mathrm{T}}$ suggested that it belonged to the genus Corynebacterium as cells stained Gram-positive and produced short, diphtheroid rods with some of the cells arranged in a $\mathrm{V}$ formation due to their snapping division (Collins \& Cummins, 1986). A representative phase-contrast micrograph of cells of strain D $7015^{\mathrm{T}}$ is available as Supplementary Fig. S1 (in IJSEM
Online). Strain $\mathrm{D} 7015^{\mathrm{T}}$ was non-motile and non-endospore-forming. The isolate was catalase-positive and oxidase-negative. The following results of carbon source assimilation were positive in API 50CH: aesculin ferric citrate, salicin, maltose and glycogen. Strain D7015 displayed a numerical profile of 3200127 with the commercial API Coryne system, which corresponded to a 'doubtful' identification as Corynebacterium glucuronolyticum (with a confidence level of $99.2 \%$ ). However, further biochemical analyses, using API ZYM and additional phenotypic tests, revealed that strain $\mathrm{D} 7015^{\mathrm{T}}$ could be distinguished from C. glucuronolyticum on the basis of its ability to produce $\alpha$-chymotrypsin and its inability to produce esterase lipase $(\mathrm{C} 4)$. Strain $\mathrm{D} 7015^{\mathrm{T}}$ produced acid from glucose, maltose, sucrose and glycogen, but not from ribose, xylose, mannitol or lactose. Strain $\mathrm{D} 7015^{\mathrm{T}}$ also differed from C. spheniscorum notably in the inability of the latter to reduce nitrate, or produce $\beta$-glucuronidase, $\alpha$ chymotrypsin or naphthol-AS-BI-phosphohydrolase. The complete morphological and biochemical characteristics of strain $\mathrm{D} 7015^{\mathrm{T}}$ are given in the species description.

Phylogenetic analyses performed with nearly complete sequences of members of closely related species (Fig. 1) showed that no sequence available in the GenBank database exhibited more than $96 \%$ similarity. The sequence similarity observed between the isolate and its closest relative, $C$. halotolerans DSM $44683^{\mathrm{T}}$, was $95.9 \%$, which is a lower value than the borderline used for defining bacterial species (i.e. $97 \%$ ) as proposed by Stackebrandt \& Goebel (1994). C. halotolerans was isolated from a saline soil sample in China (Chen et al., 2004). Growth of strain $\mathrm{D} 7015^{\mathrm{T}}$ was not observed in $10 \%(\mathrm{w} / \mathrm{v}) \mathrm{NaCl}$; however, optimum growth of C. halotolerans was in $10 \%(\mathrm{w} / \mathrm{v}) \mathrm{KCl}, \mathrm{NaCl}$ or $\mathrm{MgCl}_{2} \cdot 6 \mathrm{H}_{2} \mathrm{O}$. These two strains were also different biochemically, with strain $\mathrm{D} 7015^{\mathrm{T}}$ able to hydrolyse starch and Tweens $20-80$, but unable to produce esterase lipase $(\mathrm{C} 4)$. The DNA-DNA

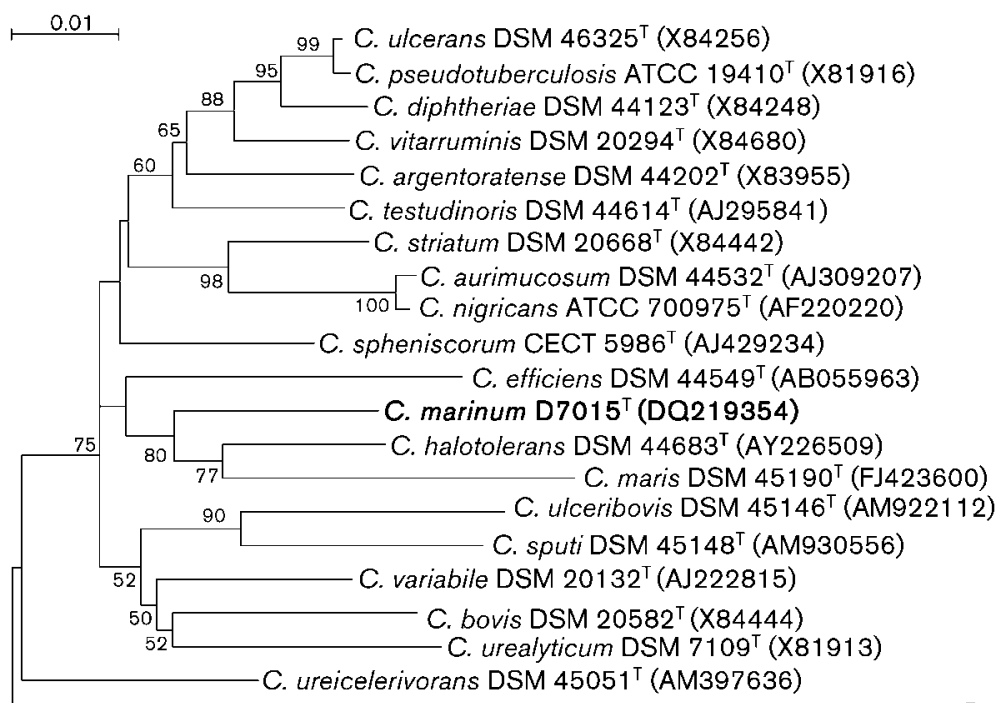

C. glucuronolyticum DSM $44120^{\top}$ (X86688)
Fig. 1. Neighbour-joining phylogeny of Corynebacterium marinum $\mathrm{D} 7015^{\top}$ and closely related strains. Numbers along branches represent bootstrap values; only values $>50 \%$ are shown. GenBank accession numbers for the $16 \mathrm{~S}$ rRNA sequences used in the tree reconstruction are given in parentheses. Bar, 0.01 substitutions per nucleotide. 
Table 1. Characteristics of strain $D 7015^{\top}$ and phylogenetically related species of the genus Corynebacterium

Strains: 1, D7015 ${ }^{\mathrm{T}}, 2$, Corynebacterium efficiens DSM $44549^{\mathrm{T}}$ (data from Fudou et al., 2002); 3, Corynebacterium halotolerans DSM $44683^{\mathrm{T}}$ (Chen et al., 2004). +, Positive; -, negative; ND, no data available.

\begin{tabular}{|lccc|}
\hline Characteristic & $\mathbf{1}$ & $\mathbf{2}$ & $\mathbf{3}$ \\
\hline Starch hydrolysis & + & $\mathrm{ND}$ & - \\
Esterase lipase $(\mathrm{C} 4)$ & - & $\mathrm{ND}$ & + \\
Growth at $45{ }^{\circ} \mathrm{C}$ & - & + & $\mathrm{ND}$ \\
Growth in $10 \%(\mathrm{w} / \mathrm{v}) \mathrm{NaCl}$ & - & + & + \\
Acid production from: & & & \\
$\quad$ Ribose & - & + & - \\
$\quad$ Maltose & + & + & - \\
$\quad$ Glycogen & + & - & - \\
DNA G+C content $(\mathrm{mol} \%)$ & 65.0 & $59.0-60.2$ & 63.0 \\
\end{tabular}

relatedness value of $20.4 \pm 0.1 \%$ (experiment repeated twice) between strain D7015 ${ }^{\mathrm{T}}$ and C. halotolerans DSM $44683^{\mathrm{T}}$ was significantly lower than $70 \%$, which is considered to be the threshold value for the delineation of genomic species (Wayne et al., 1987). Clearly, strain $\mathrm{D} 7015^{\mathrm{T}}$ differed biochemically from all of its closest relatives, both in its ability to hydrolyse casein and in its inability to produce esterase lipase (C4). The phenotypic features that differentiate strain $\mathrm{D} 7015^{\mathrm{T}}$ from its closest phylogenetic relatives are provided in Table 1.

The cellular fatty acids of strain $\mathrm{D} 7015^{\mathrm{T}}$ were $\mathrm{C}_{18: 1} \omega 9 c$ (56.18\%), $\mathrm{C}_{16: 0} \quad(38.02 \%), \mathrm{C}_{16: 1} \omega 7 c \quad(4.45 \%), \mathrm{C}_{18: 0}$ $(1.0 \%)$ and $\mathrm{C}_{14: 0}(0.35 \%)$; whole-cell fatty acid compositions of strain $\mathrm{D} 7015^{\mathrm{T}}$ and related species are available as Supplementary Table S1 in IJSEM Online. The genomic DNA G + C content was $65.0 \mathrm{~mol} \%$.

Based on these molecular, chemotaxonomic and phenotypic results, it is proposed that strain $\mathrm{D} 7015^{\mathrm{T}}$ should be classified as a representative of a novel species of the genus Corynebacterium, for which the name Corynebacterium marinum sp. nov. is proposed.

\section{Description of Corynebacterium marinum sp. nov.}

Corynebacterium marinum (ma.ri'num. L. neut. adj. marinum of the sea, marine).

Cells are short, Gram-positive, non-motile, diphtheroid rods; some cells are arranged in a V formation. Colonies on MA medium are circular, erose, convex, yellow, of a creamy consistency and $0.5-1.5 \mathrm{~mm}$ in diameter after $48 \mathrm{~h}$ at $28{ }^{\circ} \mathrm{C}$. Facultatively anaerobic, catalase-positive and oxidase-negative. Negative for the methyl red test and positive for the Voges-Proskauer test. Reduces nitrate and lyses horse blood cells. Aesculin and urea are not hydrolysed, but casein is digested and starch and pullulan are hydrolysed. Gelatin is not liquefied. Tweens $20-80$ are hydrolysed. Cells grow in the presence of $0-8 \%(w / v) ~ N a C l$ and at $4-37{ }^{\circ} \mathrm{C}$. Prolific growth occurs at $30-32{ }^{\circ} \mathrm{C}$ in media that contain $1 \%(\mathrm{w} / \mathrm{v}) \mathrm{NaCl}$. Using the API $50 \mathrm{CH}$ system, aesculin ferric citrate, salicin, maltose and glycogen are utilized. Acid is produced from glucose, maltose, sucrose and glycogen, but not from ribose, xylose, mannitol or lactose. Positive for esterase lipase (C8), leucine arylamidase, $\alpha$-chymotrypsin, naphthol-AS-BIphosphohydrolase, pyrazinamidase and $\beta$-glucuronidase activities. Negative for esterase lipase (C4), lipase (C14), valine arylamidase, cystine arylamidase, trypsin, alkaline phosphatase, pyrrolidonyl arylamidase, acid phosphatase, $\alpha$-galactosidase, $\beta$-galactosidase, $\alpha$-glucosidase, $\beta$-glucosidase, $N$-acetyl- $\beta$-glucosaminidase, $\alpha$-mannosidase and $\alpha$ fucosidase activities. Using antibiotic discs, resistant to $(\mu \mathrm{g}$ per disc) nalidixic acid (30), nitrofurantoin (50), sulphamethizole (200), tetracycline (100) and cotrimoxazole (25), but sensitive to ampicillin (25), chloramphenicol (50), gentamycin (10), kanamycin (30), carbenicillin (100) and streptomycin (25). Major fatty acids are $\mathrm{C}_{18: 1} \omega 9 \mathcal{c}, \mathrm{C}_{16: 0}$, $\mathrm{C}_{16: 1} \omega 7 c, \mathrm{C}_{18: 0}$ and $\mathrm{C}_{14: 0}$.

The type strain is $\mathrm{D} 7015^{\mathrm{T}}\left(=\mathrm{CGMCC} 1.6998^{\mathrm{T}}=\mathrm{NRRL}\right.$ B-24779 ${ }^{\mathrm{T}}$ ), isolated from coastal sediment close to a coalfired power station in Qingdao, China. The genomic DNA $\mathrm{G}+\mathrm{C}$ content of the type strain is $65.0 \mathrm{~mol} \%$.

\section{Acknowledgements}

This work was supported by the Darwin Initiative Project in the UK (no. 162/8/065), the National Science Foundation of China (project no. 40730847), a Special Non-profit Research Project from the Ministry of Agriculture of China (nyhyzx 07-046) and a grant (MBSMAT-2009-07) from the Key Laboratory of Marine Bioactive Substances and Modern Analytical Techniques, State Oceanic Administration (SOA), China.

\section{References}

Ben-Dov, E., Ben Yosef, D. Z., Pavlov, V. \& Kushmaro, A. (2009). Corynebacterium maris sp. nov., a marine bacterium isolated from the mucus of the coral Fungia granulosa. Int J Syst Evol Microbiol 59, 2458-2463.

Chen, H. H., Li, W. J., Tang, S. K., Kroppenstedt, R. M., Stackebrandt, E., Xu, L. H. \& Jiang, C. L. (2004). Corynebacterium halotolerans sp. nov., isolated from saline soil in the west of China. Int J Syst Evol Microbiol 54, 779-782.

Collins, M. D. \& Cummins, C. S. (1986). Genus Corynebacterium Lehmann and Neumann 1896, 350 $\mathrm{AL}$. In Bergey's Manual of Systematic Bacteriology, vol. 2, pp. 1266-1276. Edited by P. H. A. Sneath, N. S. Mair, M. E. Sharpe \& J. G. Holt. Baltimore: Williams \& Wilkins.

Collins, M. D., Hoyles, L., Foster, G. \& Falsen, E. (2004). Corynebacterium caspium sp. nov., from a Caspian seal (Phoca caspica). Int J Syst Evol Microbiol 54, 925-928.

Cowan, S. T. \& Steel, K. J. (1974). Cowan and Steel's Manual for the Identification of Medical Bacteria, 2nd edn. London: Cambridge University Press.

De Ley, J., Cattoir, H. \& Reynaerts, A. (1970). The quantitative measurement of DNA hybridization from renaturation rates. Eur $J$ Biochem 12, 133-142. 
Du, Z., Li, Y., Yu, D., Wang, X., Chen, J., Robertson, P. A. W., Austin, B. $\& \mathrm{Xu}$, H. (2002). Heterotrophic bacterial floras in industrial area and unpolluted marine environments around Qingdao. J Ocean Univ China 1, 59-62.

Fudou, R., Jojima, Y., Seto, A., Yamada, K., Kimura, E., Nakamatsu, T., Hiraishi, A. \& Yamanaka, S. (2002). Corynebacterium efficiens sp. nov., a glutamic acid-producing species from soil and vegetables. Int $J$ Syst Evol Microbiol 52, 1127-1131.

Funke, G., Frodl, R., Bernard, K. A. \& Englert, R. (2009). Corynebacterium freiburgense sp. nov., isolated from a wound obtained from a dog bite. Int J Syst Evol Microbiol 59, 2054-2057.

Goyache, J., Vela, A. I., Collins, M. D., Ballesteros, C., Briones, V., Moreno, J., Yorio, P., Domínguez, L., Hutson, R. \& FernándezGarayzábal, J. F. (2003a). Corynebacterium spheniscorum sp. nov., isolated from the cloacae of wild penguins. Int J Syst Evol Microbiol 53, 43-46.

Goyache, J., Ballesteros, C., Vela, A. I., Collins, M. D., Briones, V., Hutson, R. A., Potti, J., García-Borboroglu, P., Domínguez, L. \& Fernández-Garayzábal, J. F. (2003b). Corynebacterium sphenisci sp. nov., isolated from wild penguins. Int J Syst Evol Microbiol 53, 10091012

Huß, V. A. R., Festl, H. \& Schleifer, K. H. (1983). Studies on the spectrophotometric determination of DNA hybridization from renaturation rates. Syst Appl Microbiol 4, 184-192.

Jahnke, K.-D. (1992). BASIC computer program for evaluation of spectroscopic DNA renaturation data from Gilford System 2600 spectrophotometer on a PC/XT/AT type personal computer. J Microbiol Methods 15, 61-73.

Jordan, E. M., Thompson, F. L., Zhang, X.-H., Li, Y., Vancanneyt, M., Kroppenstedt, R. M., Priest, F. G. \& Austin, B. (2007). Sneathiella chinensis gen. nov., sp. nov., a novel marine alphaproteobacterium isolated from coastal sediment in Qingdao, China. Int J Syst Evol Microbiol 57, 114-121.

Lane, D. J. (1991). 16S/23S rRNA sequencing. In Nucleic Acid Techniques in Bacterial Systematics, pp. 115-176. Edited by E. Stackebrandt \& M. Goodfellow. Chichester: Wiley.
Lehmann, K. B. \& Neumann, R. (1896). Atlas und Grundriss der Bakteriologie und Lehrbuch der speciellen bakteriologischen Diagnostik. Munich: J. F. Lehmann (in German).

Mesbah, M., Premachandran, U. \& Whitman, W. B. (1989). Precise measurement of the $\mathrm{G}+\mathrm{C}$ content of deoxyribonucleic acid by highperformance liquid chromatography. Int J Syst Bacteriol 39, 159-167.

Pascual, C., Foster, G., Alvarez, N. \& Collins, M. D. (1998). Corynebacterium phocae sp. nov., isolated from the common seal (Phoca vitulina). Int J Syst Bacteriol 48, 601-604.

Renaud, F. N. R., Le Coustumier, A., Wilhem, N., Aubel, D., Riegel, P., Bollet, C. \& Freney, J. (2007). Corynebacterium hansenii sp. nov., an $\alpha$ glucosidase-negative bacterium related to Corynebacterium xerosis. Int J Syst Evol Microbiol 57, 1113-1116.

Sasser, M. (1990). Identification of bacteria by gas chromatography of cellular fatty acids, Midi Technical Note 101. Newark, DE: MIDI.

Stackebrandt, E. \& Goebel, B. M. (1994). Taxonomic note: a place for DNA-DNA reassociation and $16 \mathrm{~S}$ rRNA sequence analysis in the present species definition in bacteriology. Int J Syst Bacteriol 44, 846849.

Tamaoka, J. \& Komagata, K. (1984). Determination of DNA base composition by reversed-phase high-performance liquid chromatography. FEMS Microbiol Lett 25, 125-128.

Tamura, K., Dudley, J., Nei, M. \& Kumar, S. (2007). MEGA4: Molecular evolutionary genetics analysis (MEGA) software version 4.0. Mol Biol Evol 24, 1596-1599.

Wayne, L. G., Brenner, D. J., Colwell, R. R., Grimont, P. A. D., Kandler, O., Krichevsky, M. I., Moore, L. H., Moore, W. E. C., Murray, R. G. E. \& other authors (1987). International Committee on Systematic Bacteriology. Report of the ad hoc committee on reconciliation of approaches to bacterial systematics. Int J Syst Bacteriol 37, 463-464.

Yassin, A. F. (2009). Corynebacterium ulceribovis sp. nov., isolated from the skin of the udder of a cow with a profound ulceration. Int $J$ Syst Evol Microbiol 59, 34-37.

Yassin, A. F. \& Siering, C. (2008). Corynebacterium sputi sp. nov., isolated from the sputum of a patient with pneumonia. Int J Syst Evol Microbiol 58, 2876-2879. 